\title{
PENGEMBANGAN PERANGKAT PEMBELAJARAN MATEMATIKA DENGAN PENDEKATAN REALISTIC MATHEMATIC EDUCATION POKOK BAHASAN BANGUN RUANG
}

\author{
Baharullah $^{1 *}$ \\ Syamsul Alam ${ }^{2}$ \\ 1,2Universitas Muhammadiyah Makassar, Makassar, Indonesia \\ baharullah@unismuh.ac.id ${ }^{\text {* }}$ \\ syamsul@gmail.com ${ }^{2}$
}

\begin{abstract}
Abstrak
Penelitian ini bertujuan untuk mengembangkan perangkat pembelajaran pada pokok bahasan bangun ruang dengan pendekatan Realistic Mathematics Education. Perangkat pembelajaran yang dihasilkan dalam penelitian ini meliputi: Buku Siswa, Lembar Kegiatan Siswa (LKS), Rencana Pelaksanaan Pembelajaran (RPP). Penelitian ini dilaksanakan di SMP Muhammadiyah12 Makassar, dan subjek penelitiannya adalah siswa kelas IX dengan jumlah siswa 22 orang. Penelitian ini, hanya dilakukan ujicoba terbatas sehingga masih perlu dikembangkan untuk mengukur efektivitas pembelajaran pada pokok bahasan bangun ruang sisi lengkung di kelas IX SMP dengan pendekatan matematika realistik. Pengembangan perangkat pembelajaran ini menggunakan model Thiagarajan yang terdiri dari 4 (empat) tahap, yaitu pendefinisian, perancangan pengembangan dan penyebaran. Instrumen yang di gunakan pada penelitian ini berupa RPP, LKS, dan Buku Siswa yang sudah di validasi. Dari hasil penelitian di atas dapat di simpulkan bahwa dengan menggunakan pendekatan Realistic Mathematic Education Pokok Bahasan bangun ruang siswa kelas IX SMP Muhammadiyah 12 makassar maka kesiapan dan pemahaman siswa dalam proses pembelajaran dapat berkembang dengan baik.
\end{abstract}

Kata Kunci: Pengembangan Perangkat Pembelajaran, Realistik Mathematics Education dan Bangun Ruang.

Diterbitkan Oleh:

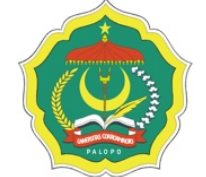

Fakultas Sains

Program Studi Matematika

Universitas Cokroaminoto Palopo

Copyright (C) 2021 The Author (s)

This article is licensed under CC BY 4.0 License

\section{(cc) $\mathrm{BY}$}




\section{PENGEMBANGAN PERANGKAT PEMBELAJARAN MATEMATIKA DENGAN PENDEKATAN REALISTIC MATHEMATIC EDUCATION POKOK BAHASAN BANGUN RUANG}

\section{Pendahuluan}

Pendidikan pada dasarnya merupakan proses untuk membantu manusia dalam mengembangkan potensi dirinya sehingga mampu menghadapi setiap perubahan yang terjadi. Dalam rangka membangun manusia yang berpendidikan seutuhnya sangat dibutuhkan pembinaan sumber daya manusia. Oleh karena itu, pendidikan sangat perlu diperhatikan oleh semua komponen mulai dari pemerintah, masyarakat, dan pengelola pendidikan pada khususnya.

Pembelajaran matematika khususnya di dunia pendidikan sering ditemukan kendala dalam proses pembelajaran. Keberhasilan proses belajar mengajar dapat diukur dari keberhasilan peserta didik yang mengikuti kegiatan pembelajaran. Keberhasilan tersebut dapat dilihat dari tingkat pemahaman materi dan prestasi belajar peserta didik. Semakin tinggi pemahaman materi dan prestasi belajar, maka semakin tinggi pula tingkat keberhasilan pembelajaran. Dalam pembelajaran matematika dibutuhkan pemahaman materi sebagai dasar untuk pengembangan materi lebih lanjut.

Russefendi (Heruman \& Ramdhani, 2012) mengemukakan bahwa matematika adalah bahasa simbol, ilmu deduktif yang menolak pembuktian secara induktif, ilmu tentang pola keteraturan dan struktur yang terorganisasi. Sehubungan dengan hal tersebut Suyono (Afandi et al., 2013) pembelajaran matematika yang dilakukan guru di sekolah adalah rendahnya kemampuan guru menggunakan metode pembelajaran yang bervariasi, kemampuan mengajar guru hanya sebatas menjawab soal-soal, guru enggan mengubah metode mengajar yang terlanjur dianggap benar dan efektif, dan guru hanya menggunakan metode pembelajaran konvensional tanpa memperhatikan aspek berpikir peserta didik. Salah satu upaya yang dapat dilakukan untuk mengatasi kelemahan pembelajaran matematika adalah penerapan pendekatan pembelajaran yang mampu melibatkan peserta didik secara aktif, baik fisik, emosi, maupun sosial. Salah satu pendekatan pembelajaran matematika yang memiliki profil seperti itu adalah pendekatan pembelajaran matematika realistic. Pendekatan pembelajaran yang telah berhasil dilakukan di Belanda yang dikenal dengan istilah Realistic Mathematics Education (RME) (Irnawati et al., 2018). De Lange (Hobri, 2009) membedakan empat pendekatan dalam 
pendidikan matematika berdasarkan komponen matematisasinya. Pendekatan matematika berdasarkan komponen matematisasi horizontal dan matematisasi vertikal yaitu mekanistik, empiristik, strukturalistik dan realistik Pendekatan tersebut merupakan salah satu pendekatan yang dikenal dalam matematika.

Menurut Panhuizen (Wijaya, 2011), penggunaan kata "realistic" tersebut tidak sekedar menunjukkan adanya koneksi dengan dunia nyata (real-world) tetapi lebih mengacu pada fokus pendidikan matematika realistik dalam menempatkan penekanan penggunaaan suatu situasi yang bisa dibayangkan (imagineable) oleh siswa. Jadi masalah kontekstual yang dimaksud dalam penelitian ini adalah masalah yang tidak sekedar berkaitan dengan dunia nyata tapi setidaknya dapat dibayangkan oleh siswa. Pembelajaran matematika realistik awalnya di kembangkan dan di uji coba di belanda selama 25 tahun. Mathematic must be conneted to reality and mathematics as human activity yang artinya matematika harus di kaitkan dengan realita dan matematika harus dekat dengan siswa, serta relevan dengan kehidupan nyata sehari- hari (Zulkardi, 2002). Pembelajaran matematika realistic yang di maksud dalam hal ini adalah matematika sekolah yang di laksanakan dengan menempatkan realitas pengalaman siswa sebagai titik awal pembelajaran. Berdasarkan gagasan Freudenthal bahwa matematika menjadi aktivitas manusia harus dihubungkan dengan kenyataan, dekat dengan anak-anak dan harus relevan dengan masyarakat, penggunaan konteks realistik merupakan salah satu ciri yang menentukan dari pendekatan pendidikan matematika (Freudental, 2014). Freudental berkeyakinan bahwa siswa tidak boleh pandang sebagai penerima pasif matematika yg sudah jadi. Menurutnya pendidikan harus mengarahkan siswa pada penggunaan berbagai situasi dan kesempatan umtuk menemukan kembali matematika dengan cara mereka sendiri (Daryanto \& Tasrial, 2011). RME mencerminkan suatu pandangan tentang matematika sebagai sebuah subjek matter, bagaimana peserta didik belajar matematika, dan bagaimana matematika seharusnya diajarkan,pembelajaran ini di landasi oleh teori belajar kontrukvisme dengan memperioritaskan enam prinsip tercermin dalam tahap pembelajaran (Lestari, 2015).

Menurut Sapi'i, (2020) Research and Development adalah kerja kreatif yang dilakukan secara sistematis untuk menambah khasanah pengetahuan dan memanfaatkannya untuk merancang berbagai aplikasi. Sedangkan Briggs (Aji, 2016), model adalah seperangkat prosedur yang berurutan untuk mewujudkan suatu proses, seperti penilaian suatu kebutuhan, pemilihan media, dan evaluasi. Sesuai dengan pengertian tersebut, maka model pengembangan pembelajaran adalah seperangkat prosedur yang berurutan untuk melaksanakan pengembangan pembelajaran. Model-model pengembangan pembelajaran menurut Wijayanty (Musdalifah, 2019) antara lain model dari degeng dan model 4-D (model Thiagarajan). 


\section{Metode Penelitian}

Jenis penelitian pengembangan (Research and Development) meliputi pengembangan perangkat pembelajaran yang terdiri dari (1) Buku Siswa; (2) Lembar Kegiatan Siswa; dan (3) Rencana Pembelajaran. Pengembangan perangkat pembelajaran matematika yang digunakan mengacu pada model 4-D Thiagarajan. Hal ini disebabkan karena model 4-D lebih terperinci dan lebih luas pengembangannya dibanding model yang lain. Model ini merupakan sistem pendekatan pengembangan pembelajaran yang dilakukan dalam 4 tahap, yaitu pendefinisian, perancangan, pengembangan dan penyebaran. Pada tahap penyebaran belum dapat dilakukan dalam penelitian ini disebabkan karena keterbatasan waktu dan biaya yang dimiliki oleh peneliti. Adapun tahap-tahap pengembangan model 4-D (Musdalifah, 2019) yang digunakan adalah tahap pendefinisian, tahap perancangan, tahap pengembangan dan tahap penyebaran. Untuk memperoleh informasi tentang aktivitas siswa dan guru selama kegiatan pembelajaran matematika realistik, keterampilan siswa, respon siswa terhadap pembelajaran matematik realistik dan pengelolaan guru dalam kegiatan belajar mengajar, maka perlu mengembangkan instrumen.

\section{Hasil dan Pembahasana}

\section{A. Pengembangan Pernagkat Pembelajaran Matematika}

\section{Tahap Pendefenisian}

a. Analisis Awal-Akhir

Dalam penelitian ini, peneliti menemukan bahwa selama ini kegiatan pembelajaran cenderung didominasi oleh guru. Guru menjelasakan materi dengan ceramah, Rumusrumus diberikan secara langsung dan siswa diminta untuk menghapalnya sehingga saat siswa lupa terhadap rumus-rumus tersebut, meraka akan merasa bahwa matematika itu sulit karena tidak disertai dengan pemahaman. Demikian pula dalam menyelesaikan soal-soal latihan, guru lebih banyak memberikan petunjuk-petunjuk penyelesaiannya, dan siswa kurang mendapat kesempatan untuk menyelesaikannya sendiri. Tanpa harus menyadari bahwa sistem pembelajaran seperti ini akan menyebabkan siswa menjadi pasif dalam kegiatan pembelajaran dan membuat mereka berpersepsi negatif terhadap matematika. Untuk mengatasi masalah diatas, sejalan dengan tantangan dan tuntutan pembelajaran masa depan yang menghendaki pembelajaran yang lebih berpusat pada siswa, peran guru lebih sebagai fasilitator dan siswa mengkonstruksi sendiri 
pengetahuannya, dan dengan melakukan telaah terhadap Kurikulum Tingkat Satuan Pendidikan (KTSP) yang menenkankan pada kompetensi yang merupakan pengetahuan, keterampilan, pengenalan, dan pemahaman berfikir deduktif yang mengarahkan kepada kecermatan serta sistematika berpikir dan bertindak. Dari hal tersebut diperoleh deskripsi kegiatan pembelaran yang dianggap sesuai yaitu Realistic Mathematic Education (RME) maka peneliti merancang perangkat pembelajaran matematika untuk materi bangun ruang sisi lengkung berdasarkan Kurikulum Berbasis Kompetensi untuk Sekolah Menengah Pertama bahwa strategi pembelajaran matematika realistik ditandai dengan optimalisasi seluruh unsur yang ada untuk membangun pemahaman secara mandiri, sehingga materi yang cocok untuk matematika realistik adalah pokok bahasan bangun ruang sisi lengkung. Hal ini disebabkan materi tersebut erat kaitannya dengan kehidupan sekitar siswa.

b. Analisis Siswa

Pada analisis siswa tentang karakteristik siswa yang diberikan sesuai dengan karakteristik matematika realistik yang meliputi latar belakang kemampuan akademik siswa kelas IX dan perkembangan kognitif siswa. Pengetahuan yang harus dikuasai siswa untuk mempelajari pokok bahasan bangun ruang sisi lengkung adalah pengetahuan tentang pengukuran. Terkait tingkat perkembangan kognitif siswa kelas IX sekolah menengah pertama sudah mampu memahami pengukuran dengan bantuan benda-benda kongkrit.

c. Analisis Konsep

Dari hasil analisis konsep diperoleh bahwa pengetahuan yang harus dimiliki oleh siswa untuk mempelajari pokok bahasan bangun ruang sisi lengkung adalah pengetahuan siswa tentang operasi-operasi hitung yang meliputi penjumlahan, pengurangan, perkalian, dan pembagian. Materi yang menjadi prasyarat untuk materi ini adalah materi tentang luas lingkaran dan volume bangun ruang sisi datar.

d. Analisis Tugas

Analisis tugas berdasarkan pokok bahasan bangun ruang sisi lengkung diperoleh beberapa tugas-tugas yang mengarahkan kemampuan siswa untuk menjawab tugastugas sehingga tujuan pembelajaran dapat tercapai.

e. Spesifikasi Tujuan Pembelajaran

Dilihat dari analisis konsep dan tugas diperoleh indikator pencapaian hasil belajar yang dinyatakan sebagai berikut:

1) Siswa dapat menyebutkan unsur-unsur jari-jari/diameter, tinggi, sisi, alas dari 
tabung dan kerucut;

2) Siswa dapat melukiskan jaring-jaring tabung, dan jaring-jaring kerucut;

3) Siswa dapat menghitung luas selimut tabung, kerucut, dan bola;

4) Siswa dapat menghitung volume tabung, kerucut, dan bola;

5) Siswa dapat menghitung unsur-unsur BRSL jika Volume BRSL diketahui;

6) Siswa dapat menghitung perbandingan volume tabung, kerucut, dan bola;

7) Siswa dapat menghitung besar perubahan volume tabung, kerucut, dan bola jika jari-jari berubah.

\section{Tahap Perancangan}

a. Penyusunan Tes

Dari hasil analisis konsep dan analisis tugas disusun instrumen tentang tes kemampuan siswa terhadap pokok bahasan bangun ruang sisi lengkung.

1) Pemilihan Media

Pemilihan media sesuai dari hasil analisis tugas, analisis konsep, karakteristik siswa, dan fasilitas di sekolah, maka media yang digunakan adalah kaleng susu sebagai model tabung, topi ulang tahun sebagai model kerucut dan bola basket sebagai model bola, berdasarkan pokok bahasan bangun ruang sisi lengkung.

2) Pemilihan Format

Pemilihan format dalam pengembangan perangkat pembelajaran ini meliputi isi materi adalah pokok bahasan bangun ruang sisi lengkung, strategi pembelajaran matematika realistik dan sumber belajar buku paket dan buku penunjang.

\section{3) Rancangan Awal}

Rancangan awal perangkat pembelajaran tersebut antara lain sebagai berikut:
a. Buku Siswa;
b. Lembar Kegiatan Siswa; dan
c. Rencana Pembelajaran.

\section{Tahap Pengembangan}

a. Penilaian Ahli (Reviewer)

Pada tahap pengembangan terdiri dari dua langkah yaitu penilaian ahli dan aplikasi. Penilaian ahli berarti validator menelaah semua perangkat pembelajaran. Pada penilaian ahli revisi yang dilakukan terhadap perangkat pembelajaran yang dihasilkan dapat dilihat pada Tabel 1 berikut: 
Tabel 1. Hasil Revisi Penilaian Ahli Terhadap Perangkat Pembelajaran

\begin{tabular}{l} 
Sebelum \\
\hline - $3,5 \mathrm{~cm}$ \\
- Jika jumlah rusuk pada sisi alas \\
dan sisi atas ditambah terus \\
menerus, maka akan diperoleh \\
prisma seperti gambar (ii) yang \\
sisi alas dan sisi atasnya tidak \\
berbeda dengan lingkaran.
\end{tabular}

\section{Sesudah}

- $7 / 2 \mathrm{~cm}$

- Jika jumlah rusuk diperbanyak menjadi prisma segi dua belas beraturan seperti pada gambar (ii) kemudian diperbanyak lagi menjadi prisma segi-n beraturan, maka akan diperoleh sisi alas dan sisi atasnya tidak berbeda dengan lingkaran.

- Untuk ulang tahunnya. Dita

- Dita membuat kue ulang tahun membuat kue seperti gambar di samping.

- Perhatikan kaleng susu berlebel seperti pada gambar di samping. indomilk yang ada di rumahmu. Dengan menentukan diameter dan jari-jarinya. Hitunglah volume kaleng susu tersebut?

- Garis pelukis (s) yaitu garis yang menghubungkan titik puncak kerucut dengan titik pusat keliling lingkaran.

- Luas lingkaran kerucut

- Luas lingkaran besar

- RS2

- Bila kerucut dipotong menurut garis pelukis $\mathrm{s}$ dan sepanjang atasnya, maka didapat jaringjaring kerucut. Jari-jari kerucut tersebut terdiri dari juring lingkaran yang berjari-jari $S$ dan lingkaran yang berjari-jari r.

- Sebuah kerucut mempunyai alas yang berbentuk lingkaran dengan diameter $12 \mathrm{~cm}$. Apabila panjang garis pelukisnya $10 \mathrm{~cm}$. Hitunglah luas permukaan kerucut itu?

- Perhatikan kaleng susu yang di rumahmu. Ukurlah diameter dan tingginya. Berapa minimal susu yang dapat dimuat dalam kaleng tersebut?

- Garis pelukis (s) yaitu garisyang menghubungkan titik puncak kerucut dengan titik pada keliling lingkaran.

- Luas selimut kerucut

- Luas lingkaran

- $\pi r^{2}$

- Bila kerucut dipotong menurut garis pelukis $\mathrm{s}$ dan sepanjang alasnya, maka didapat jaringjaring kerucut. Jaring-jaring kerucut tersebut terdiri dari juring lingkaran yang berjari-jari $s$ dan lingkaran yang berjari-jari $\mathrm{r}$.

- Menjelang tahun baru biasanya Andi membeli terompet. Terompet yang dibelinya kali ini berbentuk kerucut dengan diameter $12 \mathrm{~cm}$. Apabila panjang garis pelukis terompet tersebut $10 \mathrm{~cm}$, hitunglah luas permukaan terompet itu?

- Menggambar sebuah kubus - Gambarkan sebuah kubus ABCDEFG. $\quad$ ABCDEFG.

- Dengan memperhatikan gambar - Perhatikan gambar yang telah yang telah dibuat, maka di dalam kubus terbentuk berapa buah limas segi empat? dibuat, maka di dalam kubus terbentuk beberapa buah limas segi empat? Bisakah kau sebutkan berapa jumlah limas? 
- Mengambil salah satu limas sebagai contoh, misal itu PABCD.

- Sebuah tempat es-krim berbentuk kerucut mempunyai volume $30 \mathrm{p} \mathrm{cm}^{3}$.

- Jika sebuah bola dapat menempati sebuah tabung maka luas bola itu sama dengan luas selimut tabung tersebut.

- Pernakah kalian perhatikan kaleng minuman yang ada di rumahmu? Berbentuk bangun ruang apakah kaleng-kaleng tersebut?
- Mengambil salah satu limas sebagai contoh, dan bentuknya PABCD.

- Sebuah tempat es-krim berbentuk kerucut mempunyai volume $30 \pi$ $\mathrm{cm}^{3}$.

- Jika sebuah bola dapat menempati sebuah tabung maka luas permukaan bola itu sama dengan luas selimut tabung tersebut.

- Di rumah apakah kalian sering melihat kaleng susu atau kaleng minuman seperti pada gambar diatas? Bagaimana bentuk kaleng tersebut?

Pada penilaian ahli revisi yang dilakukan terjadi berulang-ulang kali. Dimulai dari buku siswa yang belum dilengkapi soal-soal latihan untuk pekerjaan rumah. Adapun saran dari ahli, yaitu apa yang akan dikonstruksi siswa di LKS tidak ditulis pada buku siswa, namun demikian penilaian ahli tentang buku siswa dapat digunakan dengan revisi kecil dengan skala penilaian baik. Pada lembar kegiatan siswa belum dimunculkan aktivitas yang akan dilakukan siswa dan yang akan dikonstruksi dalam belajar secara kooperatif, namun penilaian ahli dapat digunakan dengan revisi besar. Pada rencana pembelajaran juga belum dimunculkan letak pendekatan realistiknya tetapi secara umum penilaian ahli tentang rencana pembelajaran ini adalah dapat digunakan dengan revisi kecil dengan skala penilaian baik.

b. Aplikasi

Hasil analisis deskriptif secara kuantitatif penguasaan matematika setelah diberi tindakan pada tes hasil belajar dapat dilihat pada Tabel 2 .

Tabel 2. Statistik Skor Hasil Belajar Matematika Siswa Kelas IX SMP Muhammadiyah 12 Makassar

\begin{tabular}{cc}
\hline Statistik & Nilai Statistik \\
\hline Subjek Penelitian & 22 \\
Skor Maksimum & 100 \\
Rata-rata & 66,59 \\
Standar Deviasi & 1,36 \\
Rentang Skor & 50,00 \\
Skor Tertinggi & 90,00 \\
Skor Terendah & 40,00 \\
Median & 70,00 \\
\hline
\end{tabular}


Di atas menunjukkan bahwa hasil belajar siswa kelas IX SMP Muhammadiyah 12 Makassar terhadap pelajaran matematika diperolah skor rata-rata 66,59 dari skor ideal 100,00 dengan standar deviasi 1,36. Hal ini menunjukkan bahwa siswa memiliki hasil belajar dalam kategori tinggi. Sedangkan secara individual, skor yang dicapai siswa tersebar dari skor minimum yaitu 40,00 dan skor maksimum 90,00 dengan rentang skor 50,00 .

Jika skor hasil belajar dikelompokkan dalam lima kategori, maka diperoleh distributif frekuensi pada Tabel 3 berikut:

Tabel 3. Distributif Frekuensi dan Persentase Skor Hasil Belajar Matematika Siswa Kelas IX SMP Muhammadiyah 12 Makassar

\begin{tabular}{ccccc}
\hline No. & Nilai & Kategori & Frekuensi & Persentase \\
\hline 1 & $0-34$ & Sangat Rendah & 0 & 0 \\
2 & $35-54$ & Rendah & 4 & $18,18 \%$ \\
3 & $55-64$ & Sedang & 2 & $9,09 \%$ \\
4 & $65-84$ & Tinggi & 15 & $68,18 \%$ \\
5 & $85-100$ & Sangat Tinggi & 1 & $4,55 \%$ \\
\hline
\end{tabular}

Diatas menunjukkan bahwa dari 22 siswa pada tes hasil belajar terdapat siswa yang termasuk kategori rendah $18,18 \%$, siswa yang termasuk kategori sedang 9,09\%, siswa yang termasuk kategori tinggi $68,18 \%$ dan siswa yang termasuk kategori sangat tinggi 4,55\%. Dari skor rata-rata hasil belajar matematika seluruhnya berada dalam kategori tinggi.

Berdasarkan hasil belajar dan ketuntasan belajar tersebut di atas mengindikasikan bahwa perangkat pembelajaran yang dikembangkan dengan pendekatan matematika realistik telah layak digunakan, namun harus direvisi lagi untuk mencapai hasil belajar dan ketuntasan belajar yang maksimal.

\section{Tahap Penyebaran}

Tahap ini belum dapat dilaksanakan karena pelaksanaannya hanya berupa uji coba terbatas saja.

\section{Kesimpulan}

Berdasarkan hasil dan pembahasan, dapat disimpulkan bahwa pengembangan perangkat pembelajaran matematika terhadap siswa kelas IX SMP Muhammadiyah 12 Makassar dengan 
menggunakan pembelajaran matematika realistik adalah sebagai berikut:

1. Cara mengembangkan perangkat pembelajaran adalah dengan menggunakan model Thiagrajan yag terdiri dari 4 bagian yaitu; Pendefinisian, Perancangan, pengembngan dan penyebaran.

2. Diperoleh perangkat pembelajaran matematika realistic kelas IX Pokok bahasan bangun ruang sisi lengkung.

3. Hasil validatas istrumen perangkat pembelajaran bahwa hasil validitas instrumen kriteria valid.

4. Hasil validitas instrumen LKS berada pada krateria valid.

5. Hasil aplikasi perangkat pembeljaran matematika realistic menunjukan bahwa

a) Skor rata-rata siswa dalam tes hasil belajar adalah $66,59 \%$ dengan standar deviasi $1,36 \%$ dari skor ideal 100

b) Aktivitas siswa menunjukan kecendrungan positif

c) Aktifitas guru menunjukan kecendrungan positif

d) Respon siswa terhadap oerangkat pembelajaran matematika realistic pada umumnya positif. mereka senang mempelajari perangkat pembelajarn yang di berikan.

e) Hasil pengamatan pengelola kegiatan pembelajaran matematika realistic menunjukan bahwa kondisi kelas perlahan-lahan dapat terkendali dengan baik.

\section{DAFTAR PUSTAKA}

Afandi, M., Chamalah, E., \& Wardani, O. P. (2013). Model Dan Metode Pembelajaran Di Sekolah. In Perpustakaan Nasional Katalog Dalam Terbitan (KDT) (Vol. 392, Issue 2). https://doi.org/10.1007/s00423-006-0143-4

Aji, W. N. (2016). Model Pembelajaran Dick and Carrey Dalam Pembelajaran Bahasa Dan $\begin{array}{lllll}\text { Sastra Indonesia. Kajian Linguistik Dan } & \text { Sastra, }\end{array}$ https://doi.org/10.23917/kls.v1i2.3631

Daryanto, \& Tasrial. (2011). Konsep Pembelajaran Kreatif.

Freudental, H. (2014). Revisiting Mathematics Education. In Catalysis Science and Technology (Vol. 4, Issue 9). https://doi.org/10.1039/c4cy00639a

Heruman, \& Ramdhani. (2012). Model Pembelajaran Matematika DI Skeolah Dasar. PT Remaja Rosdakarya.

Hobri. (2009). Model Mosel Pembelajaran Inovatif.

Irnawati, I., Halimah, A., \& Abrar, A. I. P. (2018). Pengembangan Perangkat Pembelajaran Matematika Berbasis Pendekatan RME Setting Kooperatif Tipe STAD Pokok Bahasan 
Persamaan Linear Dua Variabel Pada Peserta Didik Kelas VIII SMP Negeri 1 Sungguminasa. Al-Khwarizmi: Jurnal Pendidikan Matematika Dan Ilmu Pengetahuan Alam, 6(1), 57-66. https://doi.org/10.24256/jpmipa.v6i1.411

Lestari, K. E. (2015). Penelitian Pendidikan Matematika. Refika Adhitama.

Musdalifah. (2019). Pengembangan perangkat pembelajaran matematika model realistik setting kooperatif (resik) pokok bahasan himpunan pada siswa kelas vii mts. Jurnal Pendidikan Matematika, 2(3).

Purnama, S. (2013). Produk Pembelajaran Bahasa Arab. Literasi, 4(1), 19-32.

Sapi'i. (2020). Jurnal Paedagogy : Pengembangan Perangkat Pembelajaran Sistem Persamaan Linear Dua Variabel Melalui Pendekatan Realistic Mathematic Education Sapi ' i Jurnal Paedagogy: Hasil observasi kegiatan pembelajaran matematika di SMPN 2 Batukliang, Kabupaten mem. Jurnal Paedagogy, 7(3), 201-209.

Wijaya, A. (2011). Pendidikan Matematika Realistik (Pertama). Graha Ilmu.

Zulkardi. (2002). Developing A Learning Environment On Realistic Mathematics Education For Indonesian Student Teacher (Doctoral disertation, University of Twente, Enschede). $1-218$. 